National and Global Petroleum Assessment

\title{
Assessment of Undiscovered Continuous Oil and Gas Resources in the Monterey Formation, Los Angeles Basin Province, California, 2015
}

\begin{abstract}
Using a geology-based assessment methodology, the U.S. Geological Survey assessed technically recoverable mean resources of 13 million barrels of oil, 22 billion cubic feet of gas, and 1 million barrels of natural gas liquids in the Monterey Formation of the Los Angeles Basin Province, California.
\end{abstract}

\section{Introduction}

The U.S. Geological Survey (USGS) completed a geology-based assessment of technically recoverable continuous petroleum resources in the Miocene Monterey Formation in the Los Angeles Basin Province of southern California (fig. 1). Continuous petroleum accumulations are those in which oil or gas is pervasively present in essentially all wells that penetrate them, that may not be structurally or stratigraphically trapped, and that typically lack oil-water or gas-water contacts. They are commonly produced with well-stimulation technology, such as hydraulic fracturing, that is commonly referred to as "unconventional." The same stimulation technology, however, is also used in many conventionally trapped accumulations. The Monterey Formation is the source rock for the oil that accumulated in conventional structural and stratigraphic traps in the Los Angeles Basin, including the giant Wilmington and Huntington Beach oil fields.

Previous studies of the Los Angeles Basin assessed a mean of 0.98 billion barrels of undiscovered oil (Beyer, 1996) and a mean of 3.2 billion barrels of potential additions to reserves in discovered oil fields (Gautier and others, 2012). This assessment addresses potential resources in a continuous accumulation of oil in the Monterey Formation at depth, in or near the zone of petroleum generation, where petroleum that has not migrated to shallower conventional traps could still be present.

\section{Definition of Assessment Units}

Two assessment units (AUs) were defined for these rocks: (1) the Central and Eastern Los Angeles Monterey Continuous Oil AU and (2) the Western Shelf Los Angeles Monterey Continuous
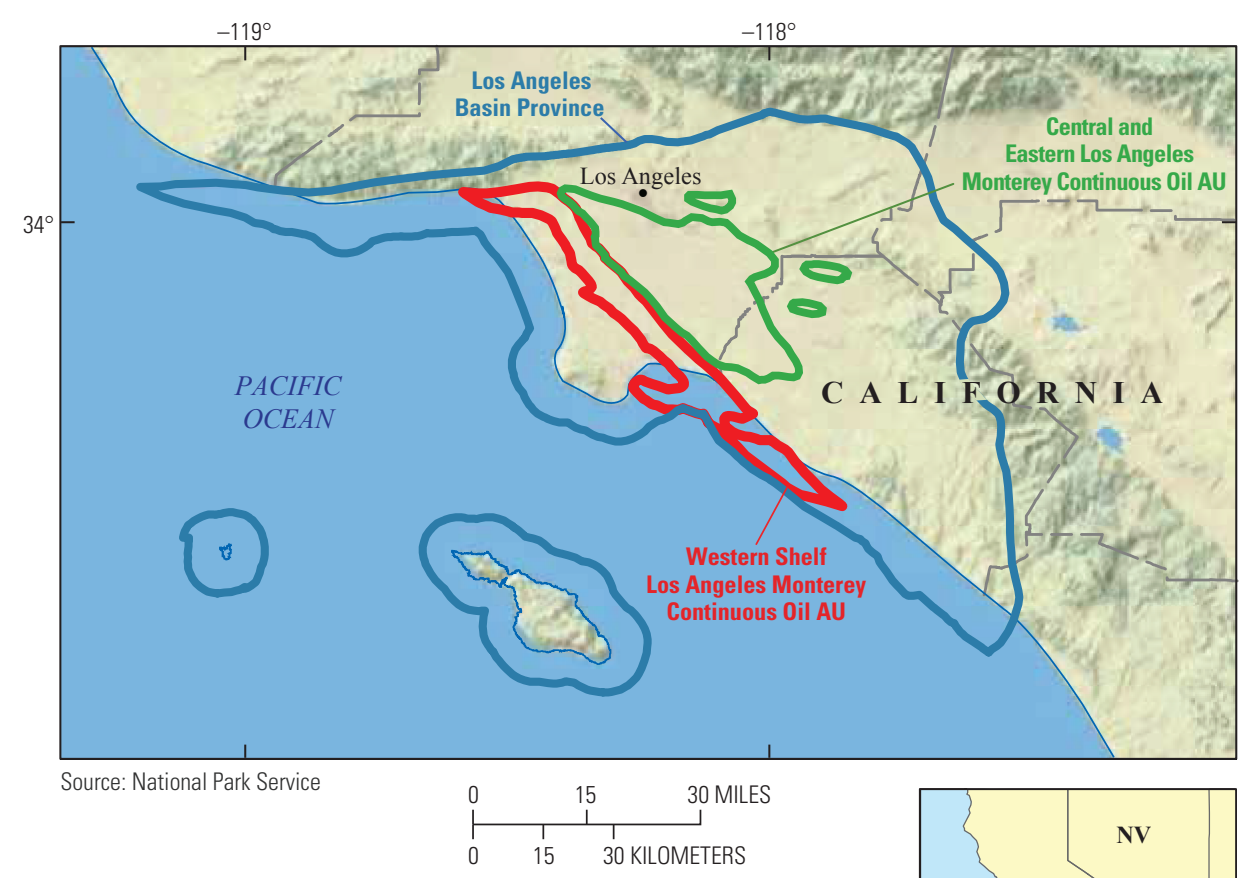

\section{EXPLANATION}
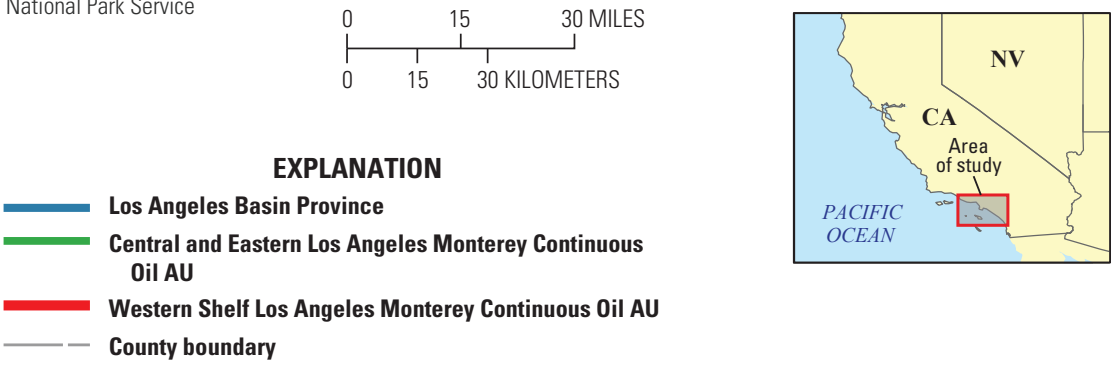

OCEAN

Figure 1. Map of the Los Angeles Basin Province in California with boundaries of the two assessments defined in this study.

Oil AU. Conventionally trapped oil and gas fields with oil-water contacts were excluded from the areas of the AUs. Assessment unit boundaries outline the areas in which generation of oil began as the base of the organic-rich Monterey Formation rocks reached burial depths of about 9,000 to $12,000 \mathrm{ft}$. The Central and Eastern Los Angeles Monterey Continuous Oil AU is defined by the -12,000-foot structure contour near the base of the Monterey Formation, from the map of Wright (1991, fig. 10). The Western Shelf Los Angeles
Monterey Continuous Oil AU includes the area west of the Newport-Inglewood fault zone where the base of the Monterey Formation is deeper than 9,000 feet, interpolated from Wright's (1991) map. Geochemical evidence suggests that the top of this zone may be about 12,000 ft deep in the eastern part of the basin but is likely to be somewhat shallower, about $9,000 \mathrm{ft}$ deep, west of the Newport-Inglewood fault zone where the organic matter in the rocks contains more sulfur, allowing it to generate oil with less heating. 
Using the southern San Joaquin Basin, where the Monterey Formation reflects a similar depositional setting, as an analog for estimating success rates, well productivity, and spacing, we concluded that although some recoverable oil may remain in the source rock, success rates (proportion of drilled wells that produce at least 2,000 barrels) will be low, and the estimated ultimate recoveries will be small even for successful wells (table 1). Wells would be relatively tightly spaced, as they are in productive Monterey Formation reservoirs in conventional traps in the San Joaquin Basin to the north.

\section{Undiscovered Resource Summary}

The USGS assessed undiscovered, technically recoverable continuous oil and gas resources in two AUs in the Monterey Formation of the Los Angeles Basin Province (table 2). Estimated mean resources are $8 \mathrm{MMBO}, 15$ billion cubic feet of gas (BCFG), and 1 million barrels of natural gas liquids (MMBNGL) in the Central and Eastern Los Angeles Monterey Continuous Oil AU and 5 MMBO,

7 BCFG, and 0 MMBNGL in the Western Shelf Los Angeles Monterey Continuous Oil AU. The estimated volumes of potential recoverable oil in deep Monterey Formation continuous accumulations are small compared to those in possible undiscovered conventional accumulations or from potential additional recovery from producing fields. Anticipated extraction methods are mostly

Table 1. Key assessment input data for the two continuous assessment units in the Los Angeles Basin Province, California.

[AU, assessment unit; \%, percent; EUR (estimated ultimate recovery per well); MMBO, million barrels of oil. The average EUR input is the minimum, median, maximum, and calculated mean. Shading indicates not applicable]

\begin{tabular}{|l|c|c|c|c|}
\hline \multirow{2}{*}{ Assessment input data } & \multicolumn{4}{c}{ Central and Eastern Los Angeles Monterey Continuous Oil AU } \\
\cline { 2 - 5 } & Minimum & Mode & Maximum & Calculated mean \\
\hline Potential production area of AU (acres) & 40,000 & 110,000 & 220,000 & 123,667 \\
\hline Average drainage area of wells (acres) & 5 & 10 & 40 & 18.3 \\
\hline Success ratio (\%) & 5 & 10 & 40 & 18.3 \\
\hline Average EUR (MMBO) & 0.003 & 0.005 & 0.02 & 0.006 \\
\hline AU probability & 1.0 & \multicolumn{4}{|c|}{} \\
\hline \multirow{2}{*}{ Assessment input data } & Western Shelf Los Angeles Monterey Continuous Oil AU \\
\cline { 2 - 6 } & Minimum & Mode & Maximum & Calculated mean \\
\hline Potential production area of AU (acres) & 20,000 & 55,000 & 127,000 & 67,333 \\
\hline Average drainage area of wells (acres) & 5 & 10 & 40 & 18.3 \\
\hline Success ratio (\%) & 5 & 10 & 50 & 21.6 \\
\hline Average EUR (MMBO) & 0.003 & 0.005 & 0.02 & 0.006 \\
\hline AU probability & 1.0 & & & \\
\hline
\end{tabular}

vertical (rather than horizontal) wells and acid stimulation; hydraulic fracturing is less likely to be successful.

\section{References Cited}

Beyer, L.A., 1996, Los Angeles Basin Province (014), in Gautier, D.L., Dolton, G.L., Takahashi, K.I., and Varnes, K.L., 1996, 1995 National Assessment of United States oil and gas resourcesResults, methodology, and supporting data: U.S. Geological Survey Data Series DDS-30, release 2, 1 CD-ROM. [Also available at http://certmapper.cr.usgs.gov/ data/noga95/prov14/text/prov14.pdf.]
Gautier, D.L., Tennyson, M.E., Cook, T.A., Charpentier, R.R., and Klett, T.R., 2012, Remaining recoverable petroleum in ten giant oil fields of the Los Angeles Basin, southern California: U.S. Geological Survey Fact Sheet 2012-3120, v. $1.1,2 \mathrm{p}$.

Wright, T.L., 1991, Structural geology and tectonic evolution of the Los Angeles Basin, California, chap. 3, part 1, of Biddle, K.T., ed., Active margin basins: American Association of Petroleum Geologists Memoir 52, p. 35-134.

Table 2. Assessment results for two continuous assessment units in the Los Angeles Basin Province, California.

[AU, assessment unit; MMBO, million barrels of oil; BCFG, billion cubic feet of gas; NGL, natural gas liquids; MMBNGL, million barrels of natural gas liquids. Results shown are fully risked estimates. F95 represents a 95 percent chance of at least the amount tabulated. Other fractiles are defined similarly. Fractiles are additive under the assumption of perfect positive correlation. Shading indicates not applicable]

\begin{tabular}{|c|c|c|c|c|c|c|c|c|c|c|c|c|c|c|}
\hline \multirow{3}{*}{$\begin{array}{l}\text { Total petroleum system and } \\
\text { assessment units (AU) }\end{array}$} & \multirow{3}{*}{$\begin{array}{l}\text { AU } \\
\text { prob- } \\
\text { ability }\end{array}$} & \multirow{3}{*}{$\begin{array}{c}\text { Accu- } \\
\text { mulation } \\
\text { type }\end{array}$} & \multicolumn{12}{|c|}{ Total undiscovered resources } \\
\hline & & & \multicolumn{4}{|c|}{ Oil (MMBO) } & \multicolumn{4}{|c|}{ Gas (BCFG) } & \multicolumn{4}{|c|}{ NGL (MMBNGL) } \\
\hline & & & F95 & $\mathrm{F} 50$ & F5 & Mean & F95 & F50 & F5 & Mean & F95 & F50 & F5 & Mean \\
\hline \multicolumn{15}{|c|}{ Monterey Total Petroleum System } \\
\hline $\begin{array}{c}\text { Central and Eastern Los Angeles } \\
\text { Monterey Continuous Oil AU }\end{array}$ & 1.0 & Oil & 2 & 6 & 19 & 8 & 3 & 11 & 37 & 15 & 0 & 0 & 2 & 1 \\
\hline $\begin{array}{l}\text { Western Shelf Los Angeles } \\
\text { Monterey Continuous Oil AU }\end{array}$ & 1.0 & Oil & 1 & 4 & 13 & 5 & 2 & 5 & 18 & 7 & 0 & 0 & 1 & 0 \\
\hline $\begin{array}{l}\text { Total undiscovered continuous } \\
\text { resources }\end{array}$ & & & 3 & 10 & 32 & 13 & 5 & 16 & 55 & 22 & $\mathbf{0}$ & $\mathbf{0}$ & 3 & 1 \\
\hline
\end{tabular}

\section{Los Angeles Basin Monterey Assessment Team}

Marilyn E. Tennyson, Ronald R. Charpentier, Timothy R. Klett, Michael E. Brownfield, Janet K. Pitman, Stephanie B. Gaswirth, Sarah J. Hawkins, Phuong A. Le, Paul G. Lillis, Kristen R. Marra, Tracey J. Mercier, Heidi M. Leathers-Miller, and Christopher J. Schenk

\section{For More Information}

Assessment results are available at the USGS Energy Resources Program Web site at http://energy.usgs.gov. 